\title{
Further occurrences of tegumental scales in caridean shrimp (Crustacea: Decapoda: Caridea)
}

\author{
Sammy De Grave and Louisa Wood
}

\begin{abstract}
Tegumental scales are documented in two families of Caridea, viz. Hippolytidae (genus Lysmata) and Rhynchocinetidae (genera Cinetorhynchus and Rhynchocinetes), raising to seven the number of families in which such scales occur. The scales in Rhynchocinetidae are similar to those in Pandalidae, but the scales in Lysmata spp. are of a slightly different type than previously documented. SEM observations reveal that the scales easily abrade and attention is drawn to the possibility that tegumental scales may be more widespread across families, but are difficult to observe. Caution is advised when considering differences in pattern (not form) between species given this high potential for abrasion. Given the low number of documented occurrences across families and genera, the potential phylogenetic information content of tegumental scales is currently unknown, but could be informative.
\end{abstract}

\section{Introduction}

Spence Bate (1888) quite possibly was the first to illustrate tegumental scales, in Heterocarpus dorsalis Spence Bate, 1888 on Plate CXI (figs 1C, Z, 2), although he does not mention them in the text and does not illustrate them for any other species of Pandalidae. Holthuis (1951) and Sivertsen \& Holthuis (1956) were the first to formally document the presence of scales on the surface of the carapace and abdomen in several genera and species of Pandalidae, variously referring to them as "scales" and "body scales". Illustrations in both works demonstrated a high similarity of these scales across species and genera, all being elongated oval in shape, ending in a slender point. Mauchline et al. (1977) carried out a survey of these scales in several genera and species in Oplophoridae, Pasiphaeidae, Pandalidae, Physetocarididae, Processidae, as well as two families in Dendrobranchiata. Their survey demonstrated the occurrence of the scales on various species of Acanthephyra (incl A. microphthalma, now transferred to Heterogenys) and Systellaspis, but failed to find them in the other taxa. Scanning electron microscopical observations as well as light microscopy revealed that the pores in which the scales are anchored are alveolated, as well as demonstrating variations in the finer detail of the scales themselves, which varies with species. Further, they demonstrated a differential orientation of the scales, with those in the anterior half of specimens (e.g. rostrum, carapace, scaphocerite) pointing anteriorly, whilst those on the posterior half (e.g. sixth pleonite, telson, uropods) point posteriorly. They concluded that this complex structure suggested a sensory function, possibly a hydrodynamic or distance sensor with scale orientation producing directional information.

Since then, various authors (e.g. Chace, 1985; Monterossa, 1988; Komai \& Chan, 2003; Fransen \& Biscoito, 2006) have documented the occurrence of these scales on several additional species and genera of carideans, primarily Pandalidae. Chace (1985) was the first to use the term "tegumental scales", and also demonstrated that minor variations in shape are present in the various species of Plesionika studied. 
Komai (2001) was the first to draw attention to their occurrence in a benthic family, Crangonidae, with further studies (Komai, 2004; 2006) documenting their presence in two more genera of Crangonidae. The earliest report of tegumental scales in Crangonidae however, must be attributed to Duris (1992) who illustrated and discussed "swollen setae" on the carapace of Vercoia gibbosa Baker. As already discussed by Komai (2001) these are near identical in form to the tegumental scales in Pandalidae (compare Chace, 1985, Fig. 8 with Duris, 1992, Fig 1G). Most recently, their occurrence has also been demonstrated in a species of Bresiliidae, Bresilia rufioculus Komai \& Yamada, 2011, with Komai \& Yamada (2011) suggesting that they also may occur in other species of that genus.

Here we document the occurrence of tegumental scales in two further families of Caridea, Hippolytidae (genus Lysmata) and Rhynchocinetidae (genera Cinetorhynchus and Rhynchocinetes). An overview is presented of all caridean species in which tegumental scales have been noted in the literature, whilst comments on their potential phylogenetic usage as well as limitations for species level characterisation are discussed.

\section{Materials and Methods}

Initial observations were by conventional light microscopy, supplemented by scanning electron microscopy (SEM) when possible. Preparation of tissue follows Martin et al. (2007), essentially hydration of tissue through a graded ethanol series to pure water, brief sonication using a light surfactant, dehydration in graded ethanol to $100 \%$, with drying done via the HMDS (hexamethyldisilazane) method. Dried specimens were coated with a gold-palladium mixture in a Polaron E5000 coating unit and observed in a JEOL JSM-5510 microscope. Initial observations highlighted that the tegumental scales were easily abraded during SEM preparation, and varying sonication times were deployed; to as short as 5 seconds or even no sonication for various preparations.

For conventional light microscopy, specimens were stained with Alizarin Red, Rose Bengal or Chlorazol Black. All specimens studied are in the Zoological Collection of the Oxford University Museum of Natural History (OUMNH.ZC).

\section{Results}

Using stained specimens under

Table 1. Species examined in the present study. Specimens examined under SEM are indicated by * (Oxford University Museum of Natural History accession numbers of material examined are listed between brackets).

\begin{tabular}{|c|c|}
\hline $\begin{array}{l}\text { Family Crangonidae } \\
\text { *Pontophilus norvegicus (M. Sars, 1861) }\end{array}$ & (OUMNH.ZC.2004-21-010) \\
\hline 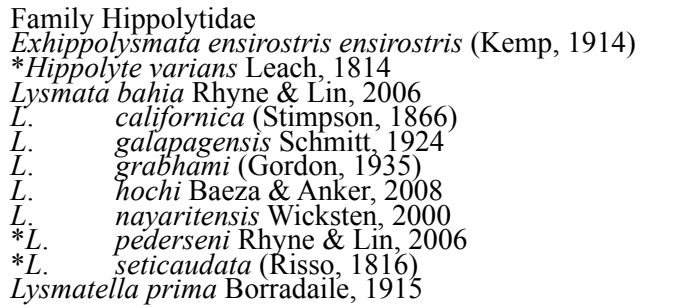 & $\begin{array}{l}\text { (OUMNH.ZC.2010-04-011) } \\
\text { (OUMNH.ZC.2004-20-010) } \\
\text { (OUMNH.ZC. } 2009-06-003) \\
\text { (OUMNH.ZC.2010-04-021) } \\
\text { (OUMNH.ZC. } 2009-06-002) \\
\text { (OUMNH.ZC. } 2010-04-028) \\
\text { (OUMNH.ZC. } 2008-14-049 \text { ) } \\
\text { (OUMNH.ZC. } 2009-18-022 \text { ) } \\
\text { (OUMNH.ZC. } 2007-20-145 \text { ) } \\
\text { (OUMNH.ZC.2007-24-003) } \\
\text { (OUMNH.ZC.2010-05-002) }\end{array}$ \\
\hline $\begin{array}{l}\text { Family Palaemonidae } \\
\text { *Palaemonetes antennarius (H. Milne Edwards, 1837) }\end{array}$ & (OUMNH.ZC.2003-03-002) \\
\hline 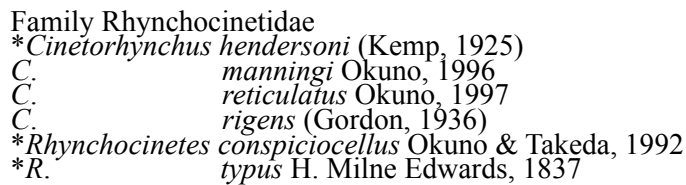 & $\begin{array}{l}\text { (OUMNH.ZC.2009-18-021) } \\
\text { (OUMNH.ZC. } 2007-20-128) \\
\text { (OUMNH.ZC.2009-23-006) } \\
\text { (OUMNH.ZC.2011-02-036) } \\
\text { (OUMNH.ZC.2009-23-008) } \\
\text { (OUMNH.ZC.2007-16-003) }\end{array}$ \\
\hline
\end{tabular}



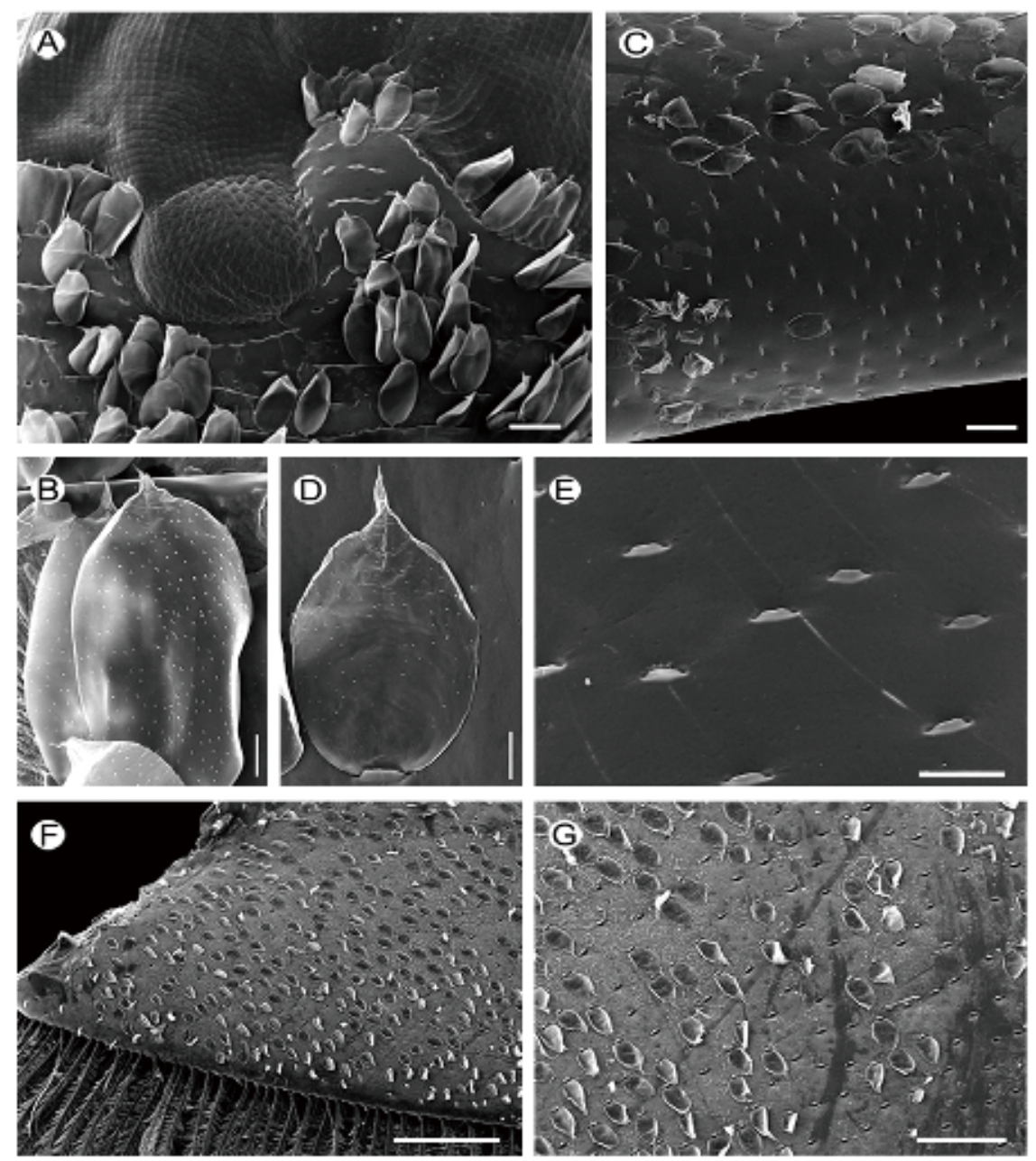

Fig. 1. Cinetorhynchus hendersoni. A, eyestalk, dorsal; B, same, tegumental scale. Rhynchocinetes conspiocellus. $\mathrm{C}$, basicerite, lateral; D, same, tegumental scale; D, pores. Rhynchocinetes typus. F, fifth pleonite, lateral; $\mathrm{G}$, same, close-up. Scale bars indicate $500 \mu \mathrm{m}(\mathrm{F}), 200 \mu \mathrm{m}(\mathrm{G}) .100 \mu \mathrm{m}(\mathrm{A}, \mathrm{C}), 50 \mu \mathrm{m}(\mathrm{E})$ or $20 \mu \mathrm{m}(\mathrm{B}, \mathrm{D})$.

conventional light microscopy, it is evident that all species of Cinetorhynchus and Rhynchocinetes (Table 1) studied harboured tegumental scales, although the extent to which they covered the carapace and abdomen varied between specimens. In most specimens, a dense covering of tegumental scales was noted on the carapace and abdomen (Fig. 1), as well as the telson and uropods, with some observed on the basal parts of the rostrum. Noticeably, tegumental scales were also present on the eye stalks (Figs. 1A, B) and the basicerite (Figs. 1C, D). In some specimens, sparse tegumental scales were present on the scaphocerite, but these were hard to observe. No scales were observed on the pereiopods, pleopods, antennular peduncle or the flagella. Tegumental scales on the carapace and abdomen up to and including the third pleonite (dorsum only) were facing anteriorly, whilst those on the fourth pleonite onwards (including the telson) faced posteriorly. Scales on the lateral sides of the pleonites (incl. the fifth pleonite) faced anteriorly, but with a noticeable ventral angle; those on the lateral side of the sixth pleonite 
faced posteriorly.

In those specimens with a sparse cover of tegumental scales, striae were very noticeable on the bare patches of carapace, rostrum and abdomen under light microscopy. Under SEM observation, it is apparent that those striae are the result of abraded tegumental scales, with the raised pores (Figs. 1C, E) occurring in a regular pattern.

The tegumental scales were of the typical pattern, inserted with a narrow stalk into a pore, being flat and wide in form, terminating

Table 2. Species of Caridea in which tegumental scales have been documented, taxonomy follows De Grave \& Fransen (2011).

\begin{tabular}{|c|c|c|}
\hline Family & Species & References \\
\hline Acanthephyridae & 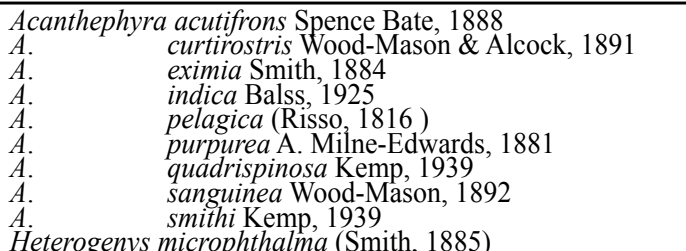 & $\begin{array}{l}\text { Mauchline et al. (1977) } \\
\text { Mauchline et al. }(1977) \\
\text { Mauchline et al. }(1977) \\
\text { Mauchline et al. }(1977) \\
\text { Mauchline et al. }(1977 \text {, as } \text { A. haeckeli) } \\
\text { Mauchline et al. }(1977) \\
\text { Mauchline et al. }(1977) \\
\text { Mauchline et al. }(1977) \\
\text { Mauchline et al. }(1977) \\
\text { Mauchline et al. }(1977 \text { as A. microphthalma })\end{array}$ \\
\hline Bresiliidae & Bresilia rufioculus Komai \& Yamada, 2011 & Komai \& Yamada (2011) \\
\hline Crangonidae & $\begin{array}{l}\text { Aegaeon lacazei (Gourret, 1887) } \\
\text { A. rathbuni (De Man, } 1918) \\
\text { Lissosabinea armata Komai, } 2006 \\
\text { L. } \quad \text { ecarina Komai, } 2006 \\
\text { L. } \quad \text { indica (De Man, 1918) } \\
\text { L. } \quad \text { tridentata (Pequegnat, 1970) } \\
\text { L. } \quad \text { unispinosa Komai, } 2006 \\
\text { Pseudopontophilus serratus Komai, } 2004 \\
\text { Vercoia gibbosa Baker } 1904\end{array}$ & $\begin{array}{l}\text { Komai }(2001) \\
\text { Komai }(2001) \\
\text { Komai }(2006) \\
\text { Komai }(2006) \\
\text { Komai }(2006) \\
\text { Komai }(2006) \\
\text { Komai }(2006) \\
\text { Komai }(2004) \\
\text { Duris }(1992)\end{array}$ \\
\hline Hippolytidae & 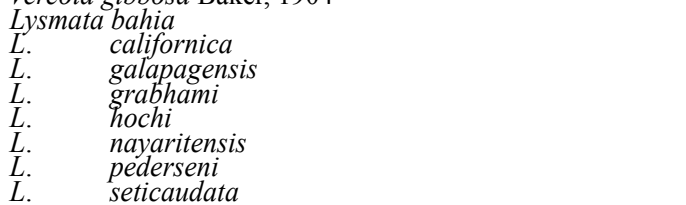 & $\begin{array}{l}\text { This study } \\
\text { This study } \\
\text { This study } \\
\text { This study } \\
\text { This study } \\
\text { This study } \\
\text { This study } \\
\text { This study }\end{array}$ \\
\hline Oplophoridae & $\begin{array}{l}\text { Systellaspis braueri braueri (Balss, 1914) } \\
\text { debilis (A. Milne Edwards } 1881 \text { ) }\end{array}$ & $\begin{array}{l}\text { Mauchline et al. (1977, as S. braueri) } \\
\text { Mauchline et al. } 1977 \text { ) }\end{array}$ \\
\hline Pandalidae & 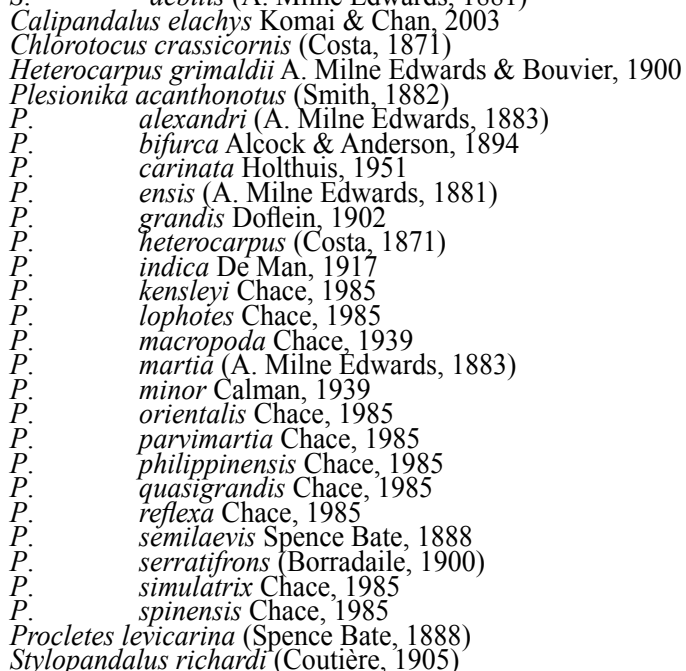 & $\begin{array}{l}\text { Komai \& Chan }(2003) \\
\text { Sivertsen \& Holthuis }(1956), \text { Chace (1985) } \\
\text { Sivertsen \& Holthuis }(1956) \\
\text { Holthuis }(1951) \\
\text { Fransen \& Biscoito (2006) } \\
\text { Chace }(1985) \\
\text { Holthuis }(1951) \\
\text { Holthuis }(1951) \\
\text { Chace }(1985) \\
\text { Holthuis }(1951) \\
\text { Chace }(1985) \\
\text { Chace }(1985) \\
\text { Chace }(1985) \\
\text { Monterossa } 1988) \\
\text { Holthuis }(1951) \\
\text { Fransen }(2006) \\
\text { Chace }(1985, \text { as } \text { P. martia orientalis) } \\
\text { Chace }(1985) \\
\text { Chace }(1985) \\
\text { Chace }(1985) \\
\text { Chace }(1985) \\
\text { Chace }(1985) \\
\text { Chace }(1985) \\
\text { Chace }(1985) \\
\text { Chace }(1985) \\
\text { Chace }(1985, \text { as Heterocarpoides levicarina) } \\
\text { Chace }(1985)\end{array}$ \\
\hline Rhynchocinetidae & 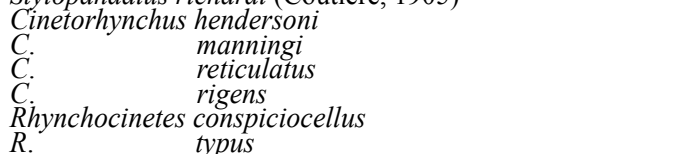 & $\begin{array}{l}\text { This study } \\
\text { This study } \\
\text { This study } \\
\text { This study } \\
\text { This study } \\
\text { This study }\end{array}$ \\
\hline
\end{tabular}



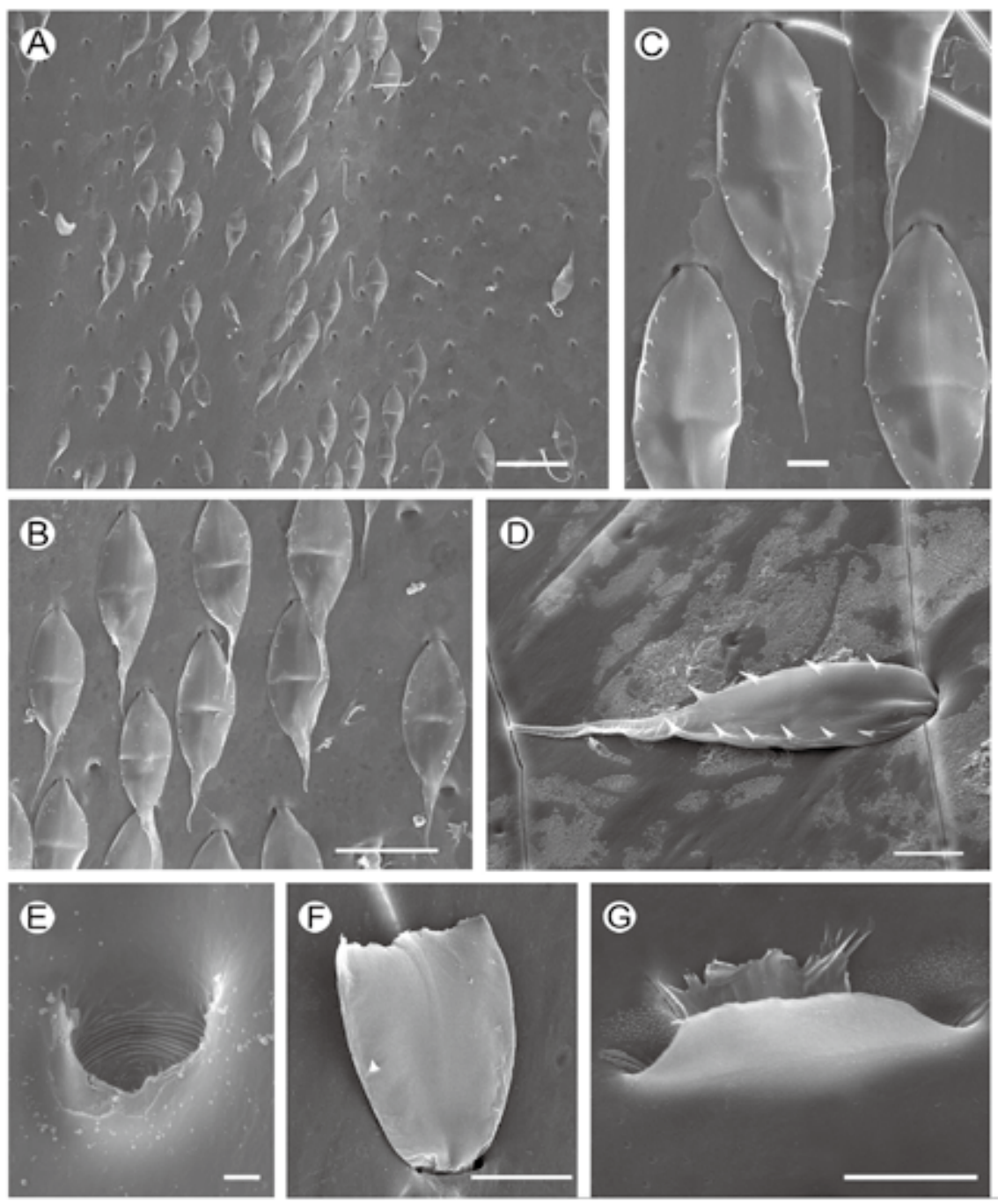

Fig. 2. Lysmata seticaudata. A, uropodal exopod, dorsal; B, same, close up; C, same, tegumental scales. Lysmata pederseni. D, sixth pleonite, tegumental scale. Lysmata seticaudata. E, uropodal exopod, pore. F, telson, broken tegumental scale. Rhynchocinetes conspiocellus. G, basicerite, broken tegumental scale. Scale bars indicate $100 \mu \mathrm{m}(\mathrm{A}), 50 \mu \mathrm{m}(\mathrm{B}), 10 \mu \mathrm{m}(\mathrm{C}-\mathrm{D}, \mathrm{F}-\mathrm{G})$ or $2 \mu \mathrm{m}(\mathrm{E})$.

in a filiform appendix. Surfaces of all scales studied under SEM were covered with denticles (Figs. 1B, D). Minor variation was noted in the fine structure of the tegumental scales, with those on the rostrum, carapace, abdomen and eye stalks not tapering distally, but being distally as wide as proximal (Fig. 1B). In contrast, those on the basicerite, uropods and telson noticeably taper more distally and have a comparatively longer filiform appendix (Fig. 1D). As the fine structure of the scales was only observed under SEM in two species, it is unclear if this difference holds across all species in the family. The pores (Figs. 1E, 2G) were characteristically raised on one margin, in the opposite direction of the scales' orientation on the body; no internal alveolation was noted.

All species of Lysmata studied (Table 1) harboured tegumental scales on the carapace, 
abdomen, uropods and telson. No scales were observed on the eyestalks, basicerite or the scaphocerite, although the latter appeared noticeably pitted in larger specimens. In most specimens a dense covering was present, although in several the scales appeared patchier, but without the striae observed in Rhynchocinetidae, instead the tegument appeared pitted. Under SEM observation it becomes clear that the pitted appearance is the result of abraded scales (Fig. 2A), with the pores being marked. The orientation of the tegumental scales was similar to the specimens of Rhynchocinetidae studied, being anterior facing in the anterior half of the body and the reverse posteriorly. No scales were observed on Lysmatella prima, or Exhippolysmata ensirostris ensirostris (Kemp, 1914), although the carapace of the latter species appeared deeply pitted when stained with Alizarin Red.

The tegumental scales are more elongate in form (Figs. 2C, D), and have a nondenticulated surface. Instead, the margin of the basal part of each scale is furnished with a low number of denticles (Fig. 2D), the filiform terminal appendix is longer, up to two-thirds of the basal part of the scale in length. In contrast to the scales in Rhynchocinetidae, all observed scales on the various body parts were essentially of the same form and structure (Figs. 2A, B). The apposing margin of the pores (Fig. 2A) is slightly raised, but less so and more rounded than in Rhynchocinetidae, internal alveolation was pronounced (Fig. 2E)

SEM observations revealed the complete absence of tegumental scales on the carapace and abdomen of Hippolyte varians, Pontophilus norvegicus and Palaemonetes varians, with the tegument being smooth, without pores present.

\section{Discussion}

The discovery of tegumental scales in Lysmata (Hippolytidae), Cinetorhynchus and Rhynchocinetes (Rhynchocinetidae) raises to seven the total number of caridean families (Table 2) in which such scales have been documented. Currently 35 families are recognised within Caridea (De Grave \& Fransen, 2011), thus tegumental scales are recognised in $2.35 \%$ of families. Although not previously recorded, the presence of scales was anticipated by statements in previous descriptions. For instance, Fransen (1991) mentioned that the tegument of Lysmata olavoi Fransen, 1991 was pitted, and covered with small scale-like hairs, clearly corresponding to the herein documented tegumental scales. Similarly, Okuno (1997) mentioned in the generic diagnosis of Cinetorhynchus that the carapace and abdomen are covered with numerous transverse striae. Komai \& Yamada (2011) already discussed that in species of Bresilia the pores of tegumental scales are seen as striae, when the scales themselves are abraded, a similar effect seen here in specimens of all genera studied.

Although tegumental scales have only been recognised in a few families and genera (Table 2), it is currently unclear as to whether they are indeed absent or just overlooked in other families and genera. During the current study it was very apparent that the scales abrade easily in preserved specimens (Figs. 1C, E; 2A, E-G), to the point whereby body parts previously observed to have a near complete coverage (e.g., telson of L. seticaudata), lost most of their scales during SEM preparation. Even reducing the sonication time to a few seconds appeared to have induced considerable loss. Mauchline et al. (1977) equally found that the majority of scales were abraded during the process of capture, with areas likely to retain some being the ventral surfaces of the scaphocerite, telson and uropods. Numerous taxonomical descriptions of carideans refer to a deeply or shallowly pitted carapace and abdomen. For example, Kensley (1983) mentions that the carapace and abdominal tegument is shallowly pitted in Discias brownae Kensley, 1983 and faintly pitted in Discias exul Kemp, 1920, a family (Disciadiidae) closely related to Bresiliidae, in which tegumental scales have been confirmed. Wicksten (2005) also mentioned that the carapace of Exhippolysmata oplophoroides (Holthuis, 1948) was coarsely pitted, herein confirmed in E. ensirostris ensirostris. This genus is 
closely related to Lysmata, and it seems possible that ultimately tegumental scales will be found. However, it needs to be pointed out that phylogenetic relatedness may not be an accurate predictor, as light microscopy of a stained specimen (Chlorazol Black) of Lysmatella prima, also related to Lysmata, did not reveal any scales or pores. Similarly, Komai (2004) noted the presence of scales in Pseudopontophilus, a genus closely related to Pontophilus, which has no scales (see above).

It is generally assumed that tegumental scales are rather ubiquitous in Pandalidae, perhaps originating with the statement in Sivertsen \& Holthuis (1956) that "Like most, if not all, other Pandalidae Chlorotocus crassicornis possesses small scales that are implanted on the integument of the carapace and the abdomen". Nevertheless they have only been documented in six out of 23 genera (Table 2). For some genera and species, it is explicitly stated in the description that no tegumental scales were found, e.g., Fransen (1997) for Chelonika macrochela Fransen, 1997 and Komai (1994, 1999) in the generic diagnosis of Pandalus and Pandalopsis. However in others, it is noted that the integument is pitted (e.g., Bitias stocki Fransen, 1990, cf. Fransen, 1990), but no actual scales were observed. Interestingly, their putative absence in the latter genus was used as one of several characters separating this genus from the more recently described Calipandalus Komai \& Chan, 2003 (cf. Komai \& Chan, 2003), supported by the observation in Chuang et al. (2003) that no tegumental scales were present in Bitias brevis (Rathbun, 1906), the only other species in the genus. A similar situation exists in the other families where tegumental scales have been observed in more than one genus, e.g., Acanthephyridae, Crangonidae, Oplophoridae, where they have only been documented in a few genera per family. Within Crangonidae, tegumental scales have been documented for four out of 23 genera (Table 1), with their putative absence noted in a further two genera; to which Pontophilus can also be added. As observed at family level, it thus remains unclear as to the distribution of tegumental scales across constituent genera, and if indeed noted absences are not simply a result of extensive abrasion.

At species level a similar picture emerges, for instance in Plesionika in which tegumental scales have been well documented (e.g., Holthuis, 1951; Sivertsen \& Holthuis, 1956; Chace, 1985), some accounts report their absence in some species (e.g., Fransen, 2006) whilst others note the presence of a pitted tegument (e.g., Squires \& Barragan 1976). Overall, they only have been recorded in 22 species (Table 2) in this species rich genus, which comprises 91 species (De Grave \& Fransen, 2011). As Plesionika spp., and other deep water Pandalidae are often recovered by remote sampling devices, such as trawls and beam trawls (Tsai et al., 2009), the potential for extensive abrasion is high, especially compared to, for instance, the individually caught (and processed) specimens of Lysmata pederseni studied herein, which nevertheless still showed differential abrasion during SEM preparation. The true intra-generic variation in presence or absence of tegumental scales is thus unclear.

Overall, it is apparent that the presence of scales, or their remnants as pores only, potentially has been overlooked in some descriptive work, perhaps because taxonomists have not considered them to be informative or more likely since specialised techniques are required to visualise them. For example, despite their presence in several species of Plesionika, the exemplary revisions by Chan (2004) and Chan \& Crosnier $(1991,1997)$ of the Indo-Pacific species do not consider them. Equally, even though Komai (2006) noted their presence in all four known species of Lissosabinea, they are not mentioned in the additional species descriptions in Taylor \& Collins (2009). As such, for the moment at least, no phylogenetic significance can be attached to their presence at higher taxonomic levels. This can only be resolved by a complete survey of their presence across the different families and constituent genera, not an easy feat given their easy abrasion.

Given the high potential for abrasion of the scales, compounded by the difficulty imposed by observation under conventional light microscopy; caution must be advised 
when using the actual pattern in which the scales are observed (e.g., Komai, 2001 for Aegaeon spp.) for species level differentiation. The current study suggests that if tegumental scales are present in a species, in life, they extensively cover the tegument, in what Mauchline et al. (1977) referred to as a sensory skin. Although we herein hypothesise that in taxa having tegumental scales, they cover the entire carapace and abdominal tegument, the extent to which they cover various appendages does seem to differ between taxa. For instance no scales were noted in the present study on the eyestalk of Lysmata spp., whilst being present in Rhynchocinetidae. Such a differential distribution may ultimately prove to be of selected phylogenetic or taxonomic significance.

Chace (1985) demonstrated differences in form of the tegumental scales in some species of Plesionika, some having pronounced distal shoulders on the main part of the scale, others more rounded. A similar difference was noted in the two species of Aegaeon by Komai (2001). Although the tegumental scales in Rhynchocinetidae are very similar to those illustrated for Acanthephyra pelagica and various Plesionika spp., the scales of Lysmata spp. are of a different form, possessing a nondenticulated surface, but with denticulated margins. In our preliminary survey we also observed form differences within one species. Equally our results demonstrate that differences exist in the pore structure associated with the scales. Combined with a more extensive study of their occurrence across taxa, a fine scale study by SEM of the form and structure of the tegumental scales as well as pore structure, may thus be very instructive and could potentially be phylogenetically informative.

\section{Acknowledgements}

L. Wood's participation in this project was made possible by a museum internship funded by the EPA/Cephalosporin Fund; C. Fransen (NCB-Naturalis) provided constructive criticism on an earlier draft.

\section{Literature Cited}

Chace, F. A. Jr., 1985. The caridean shrimps (Crustacea: Decapoda) of the Albatross Philippine Expedition, 1907-1910, Part 3: Families Thalassocarididae and Pandalidae. Smithsonian Contributions to Zoology, 411: 1-143.

Chan, T.-Y., 2004. The "Plesionika rostricrescentis (Bate, 1888)" and " $P$. lophotes Chace, 1985" species groups of Plesionika Bate, 1888, with descriptions of five new species (Crustacea: Decapoda: Pandalidae). In: Marshall, B. \& Richer de Forges, B. (eds.). Tropical Deep-Sea Benthos, vol. 23. Mémoires du Muséum national d'Histoire naturelle, 191: 293318.

, \& Crosnier, A., 1991. Crustacea Decapoda: Studies of the Plesionika narval (Fabricius, 1787) group (Pandalidae) with descriptions of six new species. In: Crosnier, A. (ed.) Résultats des Campagnes MUSORSTOM, vol. 9. Mèmoires du Musèum national d'Histoire naturelle, série A, Zoologie, 152: 413-461.

- \& - 1997. Crustacea Decapoda: Deep-sea shrimps of the genus Plesionika Bate, 1888 (Pandalidae) from French Polynesia, with descriptions of five new species. In: Crosnier, A. (ed.) Résultats des Campagnes MUSORSTOM, vol. 18. Mémoires du Muséum national d'Histoire naturelle, 176: 187-234.

Chuang, S. C., Chan, T. Y., \& Komai, T., 2003. The rare deep-sea shrimp Bitias brevis (Rathbun, 1906) (Crustacea: Decapoda: Pandalidae) from the western Pacific. Proceedings of the Biological Society of Washington: 116, 839-845.

De Grave, S., \& Fransen, C. H. J. M., 2011. Carideorum Catalogus: The recent species of the dendrobranchiate, stenopodidean, procarididean and caridean shrimps (Crustacea: Decapoda). Zoologische Mededelingen 85, 195-589.

Duris, Z., 1992. Revision of Vercoia Baker (Crustacea: Decapoda: Crangonidae). Invertebrate Taxonomy, 6: 1437-1457.

Fransen, C. H. J. M., 1990. Bitias stocki, a new genus and new species of pandalid shrimp (Crustacea, Decapoda, Caridea) in 
the eastern Atlantic Ocean. Beaufortia, 41: 67-73.

, 1991. Lysmata olavoi, a new shrimp of the family Hippolytidae (Decapoda, Caridea) from the Eastern Atlantic Ocean. Arquipélago, 9: 63-73.

- 1997. Crustacea Decapoda: Chelonika macrochela, a new genus and new species of pandalid shrimp (Caridea) from new Caledonian waters. In: Crosnier, A. (ed.) Résultats des Campagnes MUSORSTOM, vol. 18. Mémoires du Muséum national d'Histoire naturelle, 176: 177-185.

- 2006. Pandalidae (Crustacea: Decapoda) of the Sonne, Valdivia and Meteor Expeditions 1977-1987 to the Red Sea and the Gulf of Aden. Senckenbergiana maritima 36: 51-82.

— \& Biscoito, M. J., 2006. On two rare species of caridean shrimp from the hydrothermal fields Lucky Strike and Menez Gwen on the Mid-Atlantic Ridge. Zoologische Mededelingen, 80: 45-53.

Holthuis, L. B., 1951. The caridean Crustacea of Tropical West Africa. Atlantide Report Scientific Results of the Danish Expedition to the Coasts of Tropical West Africa 1945-1946, 2: 7-187.

Kensley, B., 1983. New records of bresiliid shrimp from Australia, South Africa, Caribbean, and Gulf of Mexico (Decapod: Natantia: Caridea). Smithsonian Contributions to Zoology, 394: 1-31.

Komai, T., 1994. Deep-sea shrimps of the genus Pandalopsis (Decapoda: Caridea: Pandalidae) from the Pacific coast of eastern Hokkaido, Japan, with the description of two new species. Journal of Crustacean Biology, 14: 538-559.

- 1999. A revision of the genus Pandalus (Crustacea: Decapoda: Caridea: Pandalidae). Journal of Natural History, 33: 1265-1372.

_ 2001. New record of a crangonid shrimp, Aegaeon rathbuni (Crustacea: Decapoda: Caridea) from Japan, with notes on its tegumental scales. Natural History Research, 6: 67-75.

$\longrightarrow$, 2004. A new genus and new species of Crangonidae (Crustacea, Decapoda, Caridea) from the southwestern Pacific.
Zoosystema, 26: 73-85.

- 2006. A review of the crangonid genus Lissosabinea Christoffersen, 1988 (Crustacea, Decapoda, Caridea), with descriptions of three new species from the western Pacific. Zoosystema, 28: 31-59.

—, \& Chan, T.-Y., 2003. A new genus and species of pandalid shrimp (Decapoda: Caridea) from the western Pacific. Journal of Crustacean Biology, 23: 880-889.

— \& Yamada, Y., 2011. A new species of the caridean genus Bresilia (Decapoda: Bresiliidae) discovered from a shallowwater submarine cave in Okinawa Islands, Japan. Bulletin of the National Museum of Nature and Science, Series A, Suppl. 5: 71-82.

Martin, J. W., Liu, E. M., \& Striley, D., 2007. Morphological observations on the gills of dendrobranchiate shrimps. Zoologischer Anzeiger, 246: 115-125.

Mauchline, J., Alzawa, Y., Ishimaru, T., Nishida, S., \& Marumo, R., 1977. Integumental sensilla of pelagic decapod crustaceans. Marine Biology, 43: 149-155.

Monterrosa, O.E., 1988. Heterocarpus cutressi, new species, and Plesionika macropoda Chace, 1939: Two caridean shrimps of the family Pandalidae (Crustacea: Decapoda) from Puerto Rico and the U.S. Virgin Islands. Proceedings of the Biological Society of Washington, 101: 633-639.

Okuno, J., 1997. Crustacea Decapoda: Review on the genus Cinetorhynchus Holthuis, 1955 from the Indo-West Pacific (Caridea: Rhynchocinetidae). In: Richer de Forges, B. (ed.) Les fonds meubles des lagons de Nouvelle-Calédonie (Sédimentologie, Benthos). Études \& Thèses, 3: 1-58. 1997.

Sivertsen, E., \& Holthuis, L. B., 1956. Crustacea Decapoda (The Penaeidae and Stenopodidea excepted). Report on the Scientific Results of the "Michael Sars" North Atlantic Deep-Sea Expedition 1910 5, 1-54, Plates 1-4.

Squires, H. J., \& Barragan, J. H., 1976. A new species of Plesionika (Crustacea, Decapoda, Pandalidae) from the Pacific coast of Colombia. Pacific Science, 30: 113-117.

Taylor, J., \& Collins, D. J., 2009. New records 
of the shrimp genus Lissosabinea (Caridea: Crangonidae) from Australia including descriptions of three new species and a key to the world species. Memoirs of Museum Victoria, 66: 175-187.

Tsai, P.-C., Yeh, H. M., Chan, B. K. K., \& Chan, T.-Y., 2009. Comparison between the catch composition of the French and ORE type beam trawls on deep-sea decapod crustaceans: Implications for quantitative sampling of the deep-sea decapod biodiveristy. Crustaceana: 82: 565-591.

Wicksten, M. K., 2005. Hippolytid shrimps. In: Hernandez-Aguilera, J. L., RuizNuno, J. A., Toral-Almazan, R. E., and Arenas-Fuentes, V. (Eds.) Camarones,
Langostas y Cangrejos de la Costa Este de Mexico. Volumen I. pp. 99-108. Mexico, Econatura-CONABIO.

Addresses: (SDG) (LW) Oxford University Museum of Natural History, Parks Road Oxford OX1 3PW, U.K.

E-mail: (SDG): sammy.degrave@oum. ox.ac.uk; (LW) louisa.wood@st-annes.ox.ac. uk

ReCEIVED: 3 August 2011.

ACCEPTED: 1 September 2011. 